\title{
Detection of coronavirus genomes in Moluccan naked-backed fruit bats in Indonesia
}

\author{
Paulina Duhita Anindita • Michihito Sasaki • Agus Setiyono • Ekowati Handharyani • \\ Yasuko Orba - Shintaro Kobayashi - Ibnu Rahmadani - Siswatiana Taha - Sri Adiani · \\ Mawar Subangkit $\cdot$ Ichiro Nakamura $\cdot$ Hirofumi Sawa $\cdot$ Takashi Kimura
}

Received: 1 October 2014/ Accepted: 15 January 2015/Published online: 4 February 2015

(C) Springer-Verlag Wien 2015

\begin{abstract}
Bats have been shown to serve as natural reservoirs for numerous emerging viruses including severe acute respiratory syndrome coronavirus (SARS-CoV). In the present study, we report the discovery of bat $\mathrm{CoV}$ genes in Indonesian Moluccan naked-backed fruit bats (Dobsonia moluccensis). A partial RNA-dependent RNA polymerase gene sequence was detected in feces and tissues samples from the fruit bats, and the region between the RdRp and helicase genes could also be amplified from fecal samples. Phylogenetic analysis suggested that these bat CoVs are related to members of the genus Betacoronavirus.
\end{abstract}

Keywords Bat coronavirus · Fruit bats · Indonesia

Coronaviruses (CoVs) are known to cause infections in both humans and animals, with varying symptoms ranging

P. D. Anindita · M. Sasaki · Y. Orba · S. Kobayashi ·

H. Sawa $(\bowtie)$

Division of Molecular Pathobiology, Research Center for

Zoonosis Control, Hokkaido University, North 20 West 10,

Kita-ku, Sapporo 001-0020, Japan

e-mail: h-sawa@czc.hokudai.ac.jp

A. Setiyono - E. Handharyani - M. Subangkit

Laboratory of Veterinary Pathology, Faculty of Veterinary

Medicine, Bogor Agricultural University, Bogor, Indonesia

I. Rahmadani

Veterinary Investigation and Diagnostic Center, Bukittinggi, Indonesia

S. Taha

Faculty of Agriculture, Gorontalo State University, Gorontalo, Indonesia

S. Adiani

Faculty of Animal Husbandry, Sam Ratulangi University,

Manado, Indonesia from mild respiratory illness to severe infections resulting in death [1]. In addition to the respiratory tract, coronaviruses can also affect other organs in the body, including the gastrointestinal tract, liver, kidney, and brain of both humans and animals [2]. The pandemic of severe acute respiratory syndrome (SARS) in $2002-2003$ [3, 4] and the emergence of Middle East respiratory syndrome (MERS) [5] in 2012 are examples of human infections resulting in significant mortality. In the case of SARS, the mortality rate reached $10 \%$ as a result of respiratory failure [6-8].

Coronaviruses are the largest known RNA viruses, with genomes up to $32 \mathrm{~kb}$. They belong to order Nidovirales, family Coronaviridae. These viruses possess an envelope and a single-stranded, positive-sense RNA genome [9]. Currently, four genera have been described: Alphacoronavirus, Betacoronavirus, Gammacoronavirus, and

\footnotetext{
I. Nakamura

Unit of International Cooperation, Research Center for Zoonosis

Control, Hokkaido University, Sapporo, Japan

H. Sawa

Global Institution for Collaborative Research and Education, Hokkaido University, Sapporo, Japan

H. Sawa

Global Virus Network, Baltimore, MD 21201, USA

T. Kimura $(\bowtie)$

Laboratory of Comparative Pathology, Department of Veterinary Clinical Medicine, Graduate School of Veterinary Medicine, Hokkaido University, North 18 West 9, Kita-ku,

Sapporo 060-0818, Japan

e-mail: tkimura@vetmed.hokudai.ac.jp
} 
Deltacoronavirus [10]. Members of the genera Alphacoronavirus and Betacoronavirus are known to cause human disease, whereas those of the genera Gammacoronavirus and Deltacoronavirus are causative agents of animal disease [11]. Bats are known to be reservoirs for many emerging infectious diseases that have zoonotic potential [12] and are believed to be the original source of SARSCoV [13] and MERS-CoV [14]. In Southeast Asia, bats harboring coronaviruses have been discovered in a number of countries, including the Philippines $[15,16]$ and Thailand [17]. However, there have been no studies focused on $\mathrm{CoVs}$ in Indonesia. Here, we report the discovery of bat CoVs in Moluccan naked-backed fruit bats, Dobsonia moluccensis, in Indonesia.

We collected fruit bat samples from three regions in Indonesia: Paguyaman District, Gorontalo Province (in 2012 [ $\mathrm{n}=37]$ and 2013 [ $\mathrm{n}=15]$ ); Surabaya District, East Java Province (in $2012[\mathrm{n}=3]$ ); and Yogyakarta District, Yogyakarta Special Province (in 2012 [n = 19]). All animal experiments were conducted in accordance with the ethical guidelines of the Animal Care and Use Committee of the Veterinary Teaching Hospital, Bogor Agricultural University. Fecal, tracheal swabs, and tissues samples including brain, lung, liver, spleen, and kidney from each bat were collected and placed into RNAlater (Life Technologies, Carlsbad, CA). All samples were exported to Japan with the permission of the Directorate General of Livestock and Animal Health Services, the Ministry of Agriculture, Republic of Indonesia.

Morphological features and nucleotide sequence analysis of both mitochondrial 16S rRNA and cytochrome $b$ were conducted as described previously [18] to identify the species of each fruit bat. Feces and tissue samples were subjected to RNA extraction using TRIzol Reagent (Life Technologies) according to the manufacturer's instructions. The RNAs were then screened for genomes of CoVs using a nested RT-PCR with primer sets that specifically amplify

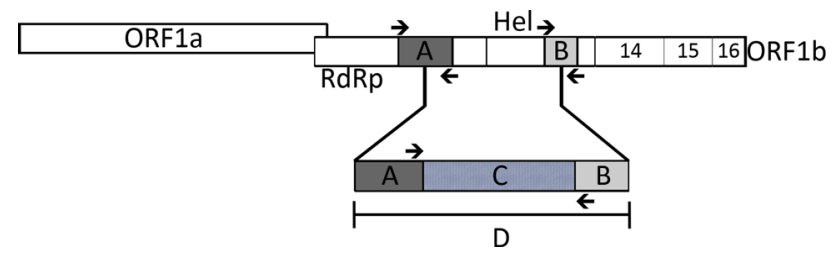

Fig. 1 Schematic diagram of genes that were amplified for detection of CoVs from fruit bats based on coronavirus replicase gene. ORF1a and ORF $1 \mathrm{~b}$ are constituents of the replicase gene. ORF1a, open reading frame 1a; RdRp, RNA-dependent RNA polymerase; Hel, helicase; ORF1b, open reading frame $1 \mathrm{~b} ; A$, partial RdRp gene (455 bp); $B$, partial helicase gene $(355 \mathrm{bp}) ; C$, region between amplified partial RdRp and partial helicase gene (1,335 bp); $D$, partial RdRp-helicase gene $(2,145 \mathrm{bp})$. Arrows indicate the orientation of the primers used for RT-PCR the conserved region of RdRp, as described previously [19] (region A in Fig. 1). The helicase region was amplified using degenerate primers specific for members of the genus Betacoronavirus [5] (region B in Fig. 1). PCR products of both the RdRp and helicase regions were gel-purified, and nucleotide sequencing was performed using a BigDye Terminator v.1.1/3.1 Cycle Sequencing Kit (Life Technologies) and analyzed using an ABI PRISM 3130 Genetic Analyzer (Life Technologies). One-step RT-PCR was performed using a new primer set and a PrimeScript II High Fidelity OneStep RT-PCR Kit (TaKaRa, Tokyo, Japan) to amplify the region not covered in the first and second sets of PCR experiments (region $\mathrm{C}$ in Fig. 1). Based on alignment of the sequences obtained in this study, the forward primer $5^{\prime}$-CACGCAACTTGTTGTAATGCGTCAGAGA- $3^{\prime}$ and the reverse primer $5^{\prime}$-CACGTGCTTTTGCAGGCACTAT ACGAC- $3^{\prime}$, corresponding to the RdRp gene at nucleotide position 14850-14877 and to the helicase gene at nucleotide position 16714-16740, respectively, of bat coronavirus (BatCoV) HKU9 (NC009021) were used. The fragments obtained, covering part of the RdRp and helicase genes (region D in Fig. 1), were sequenced.

PCR-amplified nucleotide sequences were aligned and compared to the sequences of known CoVs using the MEGA 6 program. Nucleotide sequence identity values were calculated using GENETYX software ver. 10 (GENETYX, Tokyo, Japan). Phylogenetic trees were constructed based on nucleotide sequences, using the maximum-likelihood method with the Tamura-Nei model and 1000 bootstrap replicates [20, 21].

Virus isolation was attempted by inoculation of African green monkey kidney (Vero E6), Yaeyama flying fox kidney (FBKT), and Leschenault's rousette kidney (DemKT1) cells. Vero E6 cells were obtained from Prof. Ayato Takada (Research Center for Zoonosis Control, Hokkaido University, Hokkaido, Japan) [22], and FBKT and DemKT1 cells were obtained from Prof. Ken Maeda (Yamaguchi University, Yamaguchi, Japan) [23]. Fecal and tissue homogenates that were positive for CoV RNA were used for inoculation of cells after clearance by centrifugation at $1000 \times g$ for $5 \mathrm{~min}$. Cells were incubated at $37{ }^{\circ} \mathrm{C}$ for $30 \mathrm{~min}$ with fecal samples and for $1 \mathrm{~h}$ with tissue homogenates. Inocula were replaced by fresh culture medium supplemented with $2 \%$ FBS, $2 \%$ antibioticantimycotic solution containing penicillin $(10,000 \mathrm{U} / \mathrm{ml})$, streptomycin $(10 \mu \mathrm{g} / \mathrm{ml})$ and amphotericin B $(25 \mu \mathrm{g} / \mathrm{ml})$ (Sigma, St. Louis, MO), and gentamycin $(25 \mu \mathrm{g} / \mathrm{ml})$. The supernatants of cultured cells were transferred to fresh cell monolayers each week. RNAs were extracted from culture supernatants and subjected to nested RT-PCR targeting the RdRp gene up until the fifth passage. The presence of cytopathic effect (CPE) was also checked daily until the end of the experiment. 
The species of the captured bats were shown to be $D o b$ sonia moluccensis, Acerodon celebensis, Pteropus sp. (genetically close to Pteropus hypomelanus), and Pteropus vampyrus (Table 1). Nested RT-PCR with three out of a total of 74 fecal samples from Dobsonia species produced a fragment of $455 \mathrm{bp}$ in length after removal of the primer region, which was expected size of the RdRp fragment (region $\mathrm{A}$ in Fig. 1 and Table 1). The samples were IFB2012-8F, IFB2012-13F, and IFB2012-17F. The RdRp gene is the one most commonly used for PCR amplification in $\mathrm{CoV}$ surveillance, since it contains the most regions that are conserved in all CoVs [24]. Sequence analysis demonstrated that all samples contained the sequence of the RdRpgene-conserved motifs A (DYPKCD) and C (XSDD), which form the polymerase catalytic active site [24]. The partial RdRp sequences of IFB2012-13F and IFB2012-17F were identical. There were two nucleotide substitutions when the RdRp sequences of IFB2012-13F and IFB2012-17F were compared with the RdRp sequence of IFB2012-8F.

In addition to the partial RdRp gene, a portion of the helicase gene was also amplified, producing a fragment of 355 bp (region B in Fig. 1), from the three samples that were positive for PCR targeting the RdRp region. In the helicase gene, no nucleotide differences were found between IFB2012-13F and IFB2012-17F. However, two nucleotide substitutions were observed between IFB20128F and IFB2012-13F or IFB2012-17F.

After sequencing the partial RdRp and partial helicase regions, we designed new primers to amplify the sequence between these regions (region $\mathrm{C}$ in Fig. 1). A 1335-bp fragment was detected in two samples (IFB2012-8F and IFB2012-17F). The sequence of a fragment (region D in Fig. 1), referred to as "partial RdRp-helicase", was then constructed by incorporating overlapping sequences of partial RdRp, partial helicase, and the region in between. The nucleotide sequence comparison of partial RdRp-helicase from IFB2012-8F and IFB2012-17F showed 13 nucleotide substitutions. BLAST searches showed that IFB2012-8F and IFB2012-17F had the highest nucleotide sequence identity to BatCoV HKU9-10-2 and BatCoV KY06, at $86 \%$ and $85 \%$, respectively. Following removal of primer sequences from the partial sequence of the RdRp-helicase gene at the $5^{\prime}$ and $3^{\prime}$ end, the length of the sequence was $2,116 \mathrm{bp}$, and a phylogenetic tree comparing the sequence of the samples with known CoVs, including SARS-CoV and MERS-CoV, was constructed (Fig. 2). The phylogenetic tree showed that IFB2012-8F and IFB2012-17F formed a distinct branch that was closely related to BatCoV HKU9 (NC009021), HKU9-2 (EF605514), HKU9-5-2 (HM211099), and HKU9-10-2 (HM211101) from China [25] as well as BatCoV KY06 from Kenya (HQ728483) [26]. All of these CoVs belong to the genus Betacoronavirus.

Nucleotide sequences of partial RdRp-helicase genes derived from fecal samples IFB2012-17F and IFB2012-8F were deposited under accession numbers AB918718 and AB918719, respectively, in the DNA Data Bank of Japan (DDBJ, Tokyo) nucleotide database.

Various tissues and tracheal swab samples collected from the bats where the feces yielded a positive result were also subjected to nested RT-PCR for the partial RdRp region. Spleen tissue of IFB2012-13F, brain tissue of IFB2012-17F, and lung tissue of IFB2012-17F showed positive signals for RdRp gene amplification. Sequence analysis of tissue samples showed sequences identical to the partial RdRp sequence obtained from fecal samples (IFB2012-13F and IFB2012-17F). The respiratory epithelium is known to be a target for CoVs [27], and therefore, detection of bat $\mathrm{CoV}$ genome fragments in lung samples might be expected. However, the detection of CoV genome fragments in spleen and brain samples suggested that bat $\mathrm{CoV}$ infection in these species may not be restricted to the respiratory or alimentary tract.

Attempts at virus isolation using Vero E6, FBKT, and DemKT1 cells were unsuccessful. No CPE was observed in cell cultures, and viral RNA was not detected by RT-PCR from the culture supernatants after the fifth passage.

Nucleotide sequencing and phylogenetic analysis of partial RdRp-helicase regions of the samples in the present study and these of known CoVs suggest that the CoV genome fragments obtained in this study are related to
Table 1 Detection of coronaviruses in fruit bats by nested RT-PCR targeting RdRp gene in fecal samples

\begin{tabular}{lllll}
\hline Year & Bat species & Location & $\begin{array}{l}\text { No. of samples } \\
\text { tested }\end{array}$ & $\begin{array}{l}\text { No. of positive } \\
\text { samples }\end{array}$ \\
\hline 2012 & Dobsonia mollucensis & Paguyaman & 17 & 3 \\
& Acerodon celebensis & & 18 & 0 \\
& Pteropus sp. & 2 & 0 \\
& Pteropus vampyrus & Surabaya & 3 & 0 \\
& Pteropus vampyrus & Yogyakarta & 19 & 0 \\
\multirow{2}{*}{ Total } & Acerodon celebensis & Paguyaman & 7 & 0 \\
& Pteropus vampyrus & & 8 & 0 \\
\hline
\end{tabular}




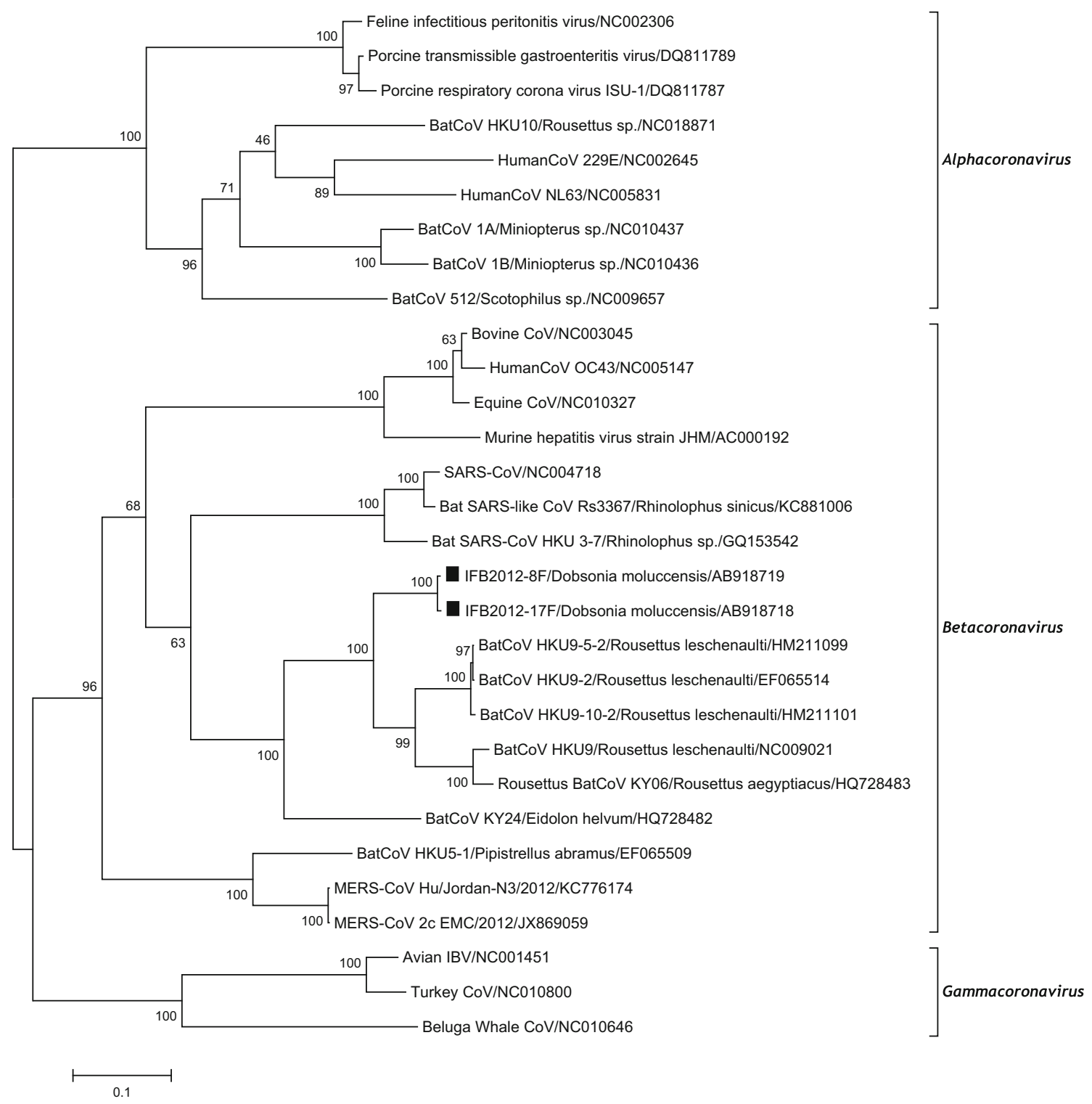

Fig. 2 Phylogenetic tree of partial RdRp-helicase using a 2,116-bp nucleotide sequence following removal of primer sequences at the $5^{\prime}$ and $3^{\prime}$ end of the partial RdRp-helicase gene obtained from fruit bats samples (IFB2012-8F and IFB2012-17F) and various coronaviruses derived from GenBank. The tree was constructed by the maximum-

those of members of the genus Betacoronavirus. More than $90 \%$ amino acid sequence identity in the conserved replicase domain, ADRP, nsp5 (3CLpro), nsp12 (RdRp), nsp13 (helicase), nsp14 (ExoN), nsp15 (NendoU), and nsp16 (O-MT) should be observed in order to include CoVs in the same species [28]. Therefore, the CoVs detected in this study could not be defined at the species level, since only certain regions of conserved replicase domains were determined. However, the number of nucleotide substitutions over the partial RdRp-helicase sequence between IFB2012-8F and IFB2012-17F and phylogenetic analysis likelihood method using MEGA 6 software. Bootstrap values were calculated for 1000 replicates and are shown next to the branches. Bat coronaviruses detected in this study are indicated by black squares. SARS-CoV, severe acute respiratory syndrome coronavirus; avian $\mathrm{IBV}$, avian infectious bronchitis virus; $\mathrm{CoV}$, coronavirus

of partial RdRp-helicase suggested that the fruit bats harbor variants of a single coronavirus strain.

In this study, CoV genomes containing regions resembling those of members of the genus Betacoronavirus were detected in Dobsonia moluccensis, known as Moluccan naked-backed fruit bat, in Indonesia. Dobsonia moluccensis belongs to family Pteropodidae, which is known to harbor a number of viruses, including CoVs [25, 29], paramyxoviruses [18, 30] and rhabdoviruses [29, 31]. Nipah and Hendra viruses have also been detected in Dobsonia moluccensis [32, 33]. 
This report highlights the fact that Indonesian fruit bats are a natural reservoir for various viruses, which have the potential to be zoonotically transmitted, since fruit bats are also consumed in certain parts of Indonesia.

Acknowledgements We thank Prof. Ayato Takada for providing the Vero E6 cell line, and Prof. Ken Maeda for providing the FBKT and DemKT1 cell lines for the current study. This study was partly supported by a grant from the Japanese Initiative of Global Research Network on Infectious Diseases (J-GRID) and a grant of the Ministry of Education, Culture, Sports, and Technology (MEXT), Japan.

\section{References}

1. Christian KA, Ijaz K, Dowell SF, Chow CC, Chitale RA, Bresee JS, Mintz E, Pallansch MA, Wassilak S, McCray E, Arthur RR (2013) What we are watching-five top global infectious disease threats, 2012: a perspective from CDC's Global Disease Detection Operations Center. Emerg Health Threats J 6:20632

2. Lelli D, Papetti A, Sabelli C, Rosti E, Moreno A, Boniotti MB (2013) Detection of coronaviruses in bats of various species in Italy. Viruses 5:2679-2689

3. Guan Y, Zheng BJ, He YQ, Liu XL, Zhuang ZX, Cheung CL, Luo SW, Li PH, Zhang LJ, Guan YJ, Butt KM, Wong KL, Chan KW, Lim W, Shortridge KF, Yuen KY, Peiris JS, Poon LL (2003) Isolation and characterization of viruses related to the SARS coronavirus from animals in southern China. Science 302:276278

4. Marra MA, Jones SJ, Astell CR et al (2003) The Genome sequence of the SARS-associated coronavirus. Science 300: 1399-1404

5. Memish ZA, Mishra N, Olival KJ, Fagbo SF, Kapoor V, Epstein JH, Alhakeem R, Durosinloun A, Al Asmari M, Islam A, Kapoor A, Briese T, Daszak P, Al Rabeeah AA, Lipkin WI (2013) Middle East respiratory syndrome coronavirus in bats, Saudi Arabia. Emerg Infect Dis 19:1819-1823

6. Drosten C, Günther S, Preiser W et al (2003) Identification of a novel coronavirus in patients with severe acute respiratory syndrome. N Engl J Med 348:1967-1976

7. Ksiazek TG, Erdman D, Goldsmith CS et al (2003) A novel coronavirus associated with severe acute respiratory syndrome. N Engl J Med 348:1953-1966

8. Rota PA, Oberste MS, Monroe SS et al (2003) Characterization of a novel coronavirus associated with severe acute respiratory syndrome. Science 300:1394-1399

9. Smith EC, Denison MR (2013) Coronaviruses as DNA wannabes: a new model for the regulation of RNA virus replication fidelity. PLoS Pathog 9:e1003760

10. Drexler JF, Corman VM, Drosten C (2014) Ecology, evolution and classification of bat coronaviruses in the aftermath of SARS. Antiviral Res 101:45-56

11. To KK, Hung IF, Chan JF, Yuen KY (2013) From SARS coronavirus to novel animal and human coronaviruses. J Thorac Dis 5(Suppl 2):S103-S108

12. Smith I, Wang LF (2013) Bats and their virome: an important source of emerging viruses capable of infecting humans. Curr Opin Virol 3:84-91

13. Ge XY, Li JL, Yang XL, Chmura AA, Zhu G, Epstein JH, Mazet JK, Hu B, Zhang W, Peng C, Zhang YJ, Luo CM, Tan B, Wang N, Zhu Y, Crameri G, Zhang SY, Wang LF, Daszak P, Shi ZL (2013) Isolation and characterization of a bat SARS-like coronavirus that uses the ACE2 receptor. Nature 503:535-538
14. Wang Q, Qi J, Yuan Y, Xuan Y, Han P, Wan Y, Ji W, Li Y, Wu Y, Wang J, Iwamoto A, Woo PC, Yuen KY, Yan J, Lu G, Gao GF (2014) Bat origins of MERS-CoV supported by bat coronavirus HKU4 usage of human receptor CD26. Cell Host Microbe $16: 328-337$

15. Watanabe S, Masangkay JS, Nagata N, Morikawa S, Mizutani T, Fukushi S, Alviola P, Omatsu T, Ueda N, Iha K, Taniguchi S, Fujii H, Tsuda S, Endoh M, Kato K, Tohya Y, Kyuwa S, Yoshikawa Y, Akashi H (2010) Bat coronaviruses and experimental infection of bats, the Philippines. Emerg Infect Dis 16:1217-1223

16. Tsuda S, Watanabe S, Masangkay JS, Mizutani T, Alviola P, Ueda N, Iha K, Taniguchi S, Fujii H, Kato K, Horimoto T, Kyuwa S, Yoshikawa Y, Akashi H (2012) Genomic and serological detection of bat coronavirus from bats in the Philippines. Arch Virol 157:2349-2355

17. Gouilh MA, Puechmaille SJ, Gonzalez JP, Teeling E, Kittayapong P, Manuguerra JC (2011) SARS-Coronavirus ancestor's foot-prints in South-East Asian bat colonies and the refuge theory. Infect Genet Evol 11:1690-1702

18. Sasaki M, Setiyono A, Handharyani E, Rahmadani I, Taha S, Adiani S, Subangkit M, Sawa H, Nakamura I, Kimura T (2012) Molecular detection of a novel paramyxovirus in fruit bats from Indonesia. Virol J 9:240

19. de Souza Luna LK, Heiser V, Regamey N, Panning M, Drexler JF, Mulangu S, Poon L, Baumgarte S, Haijema BJ, Kaiser L, Drosten C (2007) Generic detection of coronaviruses and differentiation at the prototype strain level by reverse transcriptionPCR and nonfluorescent low-density microarray. J Clin Microbiol 45:1049-1052

20. Felsenstein J (1981) Evolutionary trees from DNA sequences: a maximum likelihood approach. J Mol Evol 17:368-376

21. Tamura K, Stecher G, Peterson D, Filipski A, Kumar S (2013) MEGA6: molecular evolutionary genetics analysis version 6.0. Mol Biol Evol 30:2725-2729

22. Maruyama J, Miyamoto H, Kajihara M, Ogawa H, Maeda K, Sakoda Y, Yoshida R, Takada A (2014) Characterization of the envelope glycoprotein of a novel filovirus, lloviu virus. J Virol 88:99-109

23. Maeda K, Hondo E, Terakawa J, Kiso Y, Nakaichi N, Endoh D, Sakai K, Morikawa S, Mizutani T (2008) Isolation of novel adenovirus from fruit bat (Pteropus dasymallus yayeyamae). Emerg Infect Dis 14:347-349

24. Xu X, Liu Y, Weiss S, Arnold E, Sarafianos SG, Ding J (2003) Molecular model of SARS coronavirus polymerase: implications for biochemical functions and drug design. Nucleic Acids Res 31:7117-7130

25. Lau SK, Poon RW, Wong BH, Wang M, Huang Y, Xu H, Guo R, Li KS, Gao K, Chan KH, Zheng BJ, Woo PC, Yuen KY (2010) Coexistence of different genotypes in the same bat and serological characterization of Rousettus bat coronavirus HKU9 belonging to a novel Betacoronavirus subgroup. J Virol 84:11385-11394

26. Tong S, Conrardy C, Ruone S, Kuzmin IV, Guo X, Tao Y, Niezgoda M, Haynes L, Agwanda B, Breiman RF, Anderson LJ, Rupprecht CE (2009) Detection of novel SARS-like and other coronaviruses in bats from Kenya. Emerg Infect Dis 15:482-485

27. Hoffmann M, Müller MA, Drexler JF, Glende J, Erdt M, Gützkow T, Losemann C, Binger T, Deng H, Schwegmann-Weßels C, Esser KH, Drosten C, Herrler G (2013) Differential sensitivity of bat cells to infection by enveloped RNA viruses: coronaviruses, paramyxoviruses, filoviruses, and influenza viruses. PLoS One 8:e72942

28. King AMQ, Adams MJ, Carstens EB, Lefkowitz EJ (eds) (2012) Virus taxonomy: classification and nomenclature of viruses: Ninth Report of the International Committee on Taxonomy of Viruses. Elsevier Academic Press, San Diego, pp 809-810 
29. Calisher CH, Childs JE, Field HE, Holmes KV, Schountz T (2006) Bats: important reservoir hosts of emerging viruses. Clin Microbiol Rev 19:531-545

30. Drexler JF, Corman VM, Müller MA, Maganga GD et al (2012) Bats host major mammalian paramyxoviruses. Nat Commun 3:796

31. Nguyen AT, Nguyen TT, Noguchi A, Nguyen DV, Ngo GC, Thong VD, Olowokure B, Inoue S (2014) Bat lyssaviruses, northern Vietnam. Emerg Infect Dis 20:161-163
32. Chong HT, Abdullah S, Tan CT (2009) Nipah virus and bats. Neurology Asia 14:73-76

33. Luis AD, Hayman DT, O'Shea TJ, Cryan PM, Gilbert AT, Pulliam JR, Mills JN, Timonin ME, Willis CK, Cunningham AA, Fooks AR, Rupprecht CE, Wood JL, Webb CT (2013) A comparison of bats and rodents as reservoirs of zoonotic viruses: are bats special? Proc Biol Sci 280:20122753 